\title{
Classic sports massage vs. Chinese self-massage. Which one is more effective in warm-up?
}

\author{
Dariusz Boguszewski ${ }^{1}$, Jakub Grzegorz Adamczyk ${ }^{2}$, Aleksandra Hanc ${ }^{1}$, Agata Szymańska ${ }^{1}$, \\ Sylwia Chełchowska ${ }^{1}$, Dariusz Białoszewski ${ }^{1}$
}

${ }^{1}$ Department of Rehabilitation, Physiotherapy Division, Medical University of Warsaw, Poland; ${ }^{2}$ Institute of Theory of Sport, University of Physical Education in Warsaw, Poland

\begin{abstract}
Study aim: Warm-up is an indispensable element of sports training. The aim of the study was to determine the effect of warm-up exercises with Swedish, classic sports massage and Chinese self-massage on functional limitations of the locomotive system. Materials and methods: The study included 42 women and 13 men aged 19 to 22 . They all performed the Functional Movement Screen (FMS) test, without a warm-up, and then (after a week) performed it again after either a standard warm-up with sports massage (Group 1) or a warm-up with Chinese self-massage (Group 2).

Results: Both groups obtained significantly higher results in the second measurement (FMS test), preceded by a standard warm-up with sports massage (Group 1, $p=0.003$ ) and warm-up with Chinese self-massage (Group 2, p = 0.000). In Group 1, statistically significant differences were observed in the results of the exercises: hurdle step and push-ups. In Group 2, the difference was significant in the attempts to sit down deep, walk over the fence and pump.

Conclusion: There were no significant differences between the groups that used massage and self-massage. Both methods can improve movement functionality.
\end{abstract}

Keywords: Self-massage - Sports massage - Warm-up - Functional Movement Screen

\section{Introduction}

Correctly conducted sports training consists of three parts: the initial one - warm-up; the main one - proper exercises; and the final part - cool down. The purpose of the warm-up is to properly prepare the practitioners physically and psychophysically for the movement tasks performed in the main part and to adapt the body to the effort. The warm-up should include: aerobic exercises (increasing the body temperature), stretching exercises (stretching the muscles to be used for a specific task) and exercises consisting of movements to be used in the actual training $[3,29,38]$. An important function of warm-up is to minimise the risk of overload and injuries [34, 37]. Therefore, more and more often in the initial part of physical activity, procedures and actions characteristic for post-workout regeneration, such as stretching or self-massage, are used $[5,13,14]$. Some of the physiotherapeutic procedures are also applied before one takes up the activity; this is the case with massage or taping, for example. They can improve the quality of movement, gradually adapt to one's workout or reduce any adverse effects that may be experienced [7, 10, 15, 39].

Functional assessment can also be an additional element of injury prevention. Information on traffic quality and functional limitations is necessary to introduce a possible intervention. The tool for physiotherapist's screening can be the Functional Movement Screen (FMS) but also other tests and studies such as the Thomas Test, Core Muscle Strength and Stability Test, Thomayer's Test or Rotation Test [12, 26, 30].

The main cognitive objective of the research was to determine the impact of two forms of preparation for physical exercise (warm-up exercises preceded by an invigorating sports massage and warm-up exercises with Chinese self-massage) on the quality of movement and the degree of functional limitations in the locomotive system. 


\section{Material and methods}

Fifty-five students aged 19 to 22, who were not engaged in competitive sports, participated in the survey (Table 1). There were 42 women and 13 men. All participants were interviewed before the research was conducted to determine existing cardiovascular and respiratory diseases, as well as past damage to the locomotor system, which might hinder the test. Healthy women without the diseases and injuries mentioned above qualified for the study.

The subjects performed the Functional Movement Screen twice. The first time the test was carried out, according to the recommendations in the literature, without a warm-up. Then, after a week, the subjects were randomly divided into two groups and the test was repeated. Before re-examination, persons from Group 1 performed a warm-up preceded by a pre-workout, stimulating sports massage. Strokes, intensive rubbing and kneading were performed on the muscles of the lower, upper and dorsal extremities, along with the development of the joint area. Procedure time: 10 minutes [9]. Persons qualified for Group 2 performed a warm-up with Chinese self-massage, performing stroke and rubbing movements, longitudinal and circular, 16 repetitions each. It started with hand rubbing, followed by energetic stroking and rubbing the arms and whole upper limbs. Then the chest and abdomen were stroked. Finally, the lower limbs were worked on longitudinally (whole limbs) and circularly (knee joints) [25]. Warm-up exercises in both groups were the same. Aerobic exercises were used - running (running exercises - skips, reverse gear, crossings, etc.), and dynamic stretching exercises (circulations, bends, turns) [2]. The warm-up took about 10 minutes.

The main research tool was the Functional Movement Screen test by Gray Cook and Lee Burton [20, 21]. It was developed to provide an objective analysis of the human motor patterns in relation to functional performance and to predict and prevent injuries. Thanks to a tri-dimensional movement analysis, it is possible to detect anomalies in kinetic chains, as well as to have a comprehensive assessment identifying the asymmetry and important functional limitations, which are a result of incorrect mobility and motor system stability. FMS consists of seven exercises assessing basic movement patterns: 1. Deep squat, 2. Hurdle step, 3. In-line lunge, 4. Shoulder mobility, 5. ASLR - active straight leg raise, 6. Trunk stability push up, 7. Rotation stability [20, 21].

Performing the tasks is subject to evaluation on a fourpoint scale ( 0 to 3 points ); 3 points are granted to a person who performed the movement pattern correctly, 2 points to a person who performed the movement pattern with compensation, 1 point to a person who is not able to perform a movement pattern in its entirety, while 0 is assigned to persons who experience pain while performing the exercise or during a provocation test. The maximal score a person can achieve is 21 points [20,21].

The first FMS test was performed without any warmup, the second after a warm-up (with sports massage and Chinese self-massage). The evaluation was done in two planes, sagittal and frontal. The test person performed a given movement task three times, and the investigator recorded the best of the trials. If there were doubts as to the correctness of the pattern, a lower grade was obtained. Each side was assessed separately [20, 21].

An additional research tool was an original survey containing biometric data.

The differences between the first and second FMS measurements were calculated using the paired samples Wilcoxon test. The differences between the groups were established by the Mann-Whitney U test. The minimal significant level was adopted at $\mathrm{p} \leq 0.05$.

\section{Results}

The total measurement score of the first FMS test was similar in both groups. The results were 14.9 (Group 1) and 15.2 (Group 2), indicating mean average susceptibility to injury. In the second FMS assessment (Group 1 preceded by warm-up with sports massage and Group 2 preceded by Chinese self-massage), both groups scored significantly higher (Fig. 1).

For Group 1, statistically significant differences were observed in the results of the following tasks: hurdle step $(p=0.008)$ and trunk stability push-up $(p=0.013)$. In Group 2, significant differences were noted in the

Table 1. Characteristics of examined persons

\begin{tabular}{llccccc}
\hline Group & Gender & Number of people & Age [years] & Body mass $[\mathrm{kg}]$ & Body height $[\mathrm{cm}]$ & BMI $\left[\mathrm{kg} / \mathrm{m}^{2}\right]$ \\
\hline \multirow{2}{*}{1 (massage) } & women & 23 & $21.0 \pm 1.1$ & $65.5 \pm 11.8$ & $167.7 \pm 7.1$ & $22.7 \pm 3.0$ \\
& men & 5 & $20.6 \pm 0.9$ & $79.6 \pm 8.2$ & $181.4 \pm 4.0$ & $24.2 \pm 3.1$ \\
\multirow{2}{*}{2 (self-massage) } & women & 19 & $20.4 \pm 0.8$ & $61.5 \pm 8.9$ & $166.5 \pm 4.6$ & $22.1 \pm 2.5$ \\
& men & 8 & $20.1 \pm 0.4$ & $76.2 \pm 9.3$ & $180.3 \pm 3.8$ & $23.4 \pm 2.9$ \\
\hline
\end{tabular}




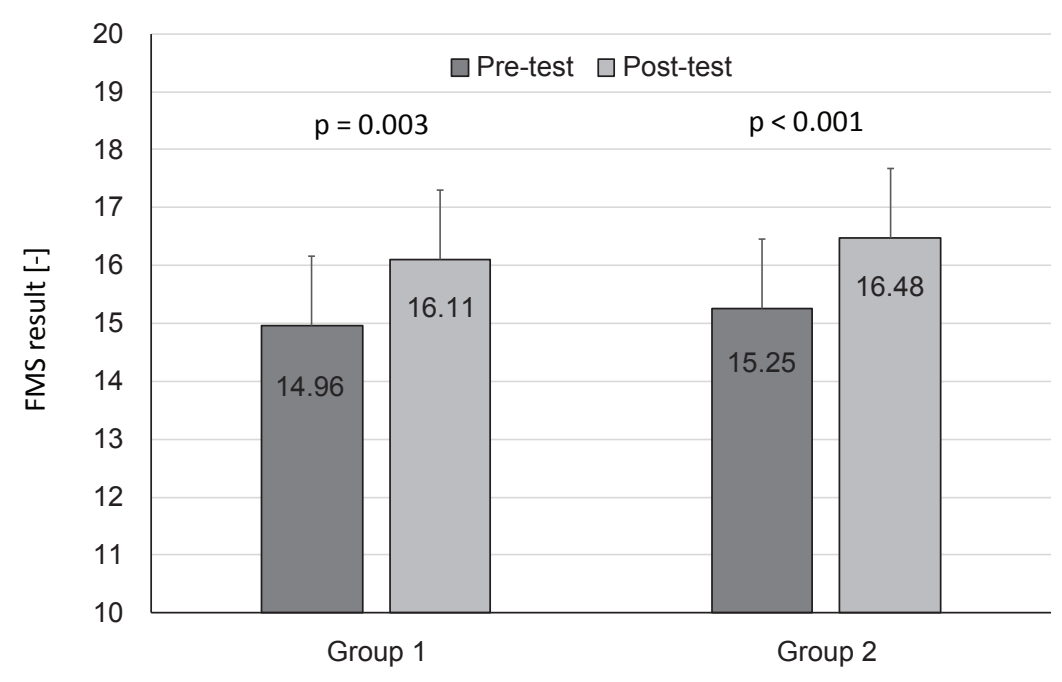

Fig. 1. Overall results of FMS

following tests: deep squat $(\mathrm{p}=0.013)$, hurdle step $(\mathrm{p}=0.016)$, and trunk stability push-up $(\mathrm{p}=0.048)$. Only in the rotary trunk stability exercise was a slightly lower result obtained in the second test (Table 2).

Among Group 1 women, the greatest differences between the results of both measurements were observed in the following tasks: hurdle step $(p=0.002)$ and trunk stability push-up $(\mathrm{p}=0.021)$. Group 2 women achieved a significant improvement in three attempts: deep squat $(\mathrm{p}=0.002)$, hurdle step $(\mathrm{p}=0.009)$ and push-up $(\mathrm{p}=0.048)$. Men from both groups had a lower total FMS score than women. The highest progression of the results (close to statistical significance) after the intervention was recorded in deep squat and active straight leg lift in Group 1 and active straight leg lift in Group 2 (Table 3).

\section{Discussion}

Physical activity is one of the main elements of a healthy lifestyle. However, it is important that the movement is safe and the training does not impair the functional capabilities of the body. Therefore, a proper warm-up is necessary, which can be supported by physiotherapy techniques. Methods that help to minimise the adverse effects of fatigue and reduce the risk of injury, i.e. supplementary exercises (stretching) and treatments (massage, selfmassage), should be an important element of training both among professional and recreational athletes [14, 32]. Our own research has demonstrated that warm-up exercises with both sports massage and self-massage have a positive effect on minimizing the locomotive system's functional limitations. This confirms that warm-up before training is a very important aspect of anti-injury prevention [34, 37].

The positive effect of warm-up in anti-injury prophylaxis is confirmed by studies conducted by Subasi et al., Maiiou et al. and Obałkowska whereby warm-up exercises significantly affected proprioception, sense of balance and muscle function $[28,31,36]$.

Massage is considered as one of the most effective methods positively affecting muscle regeneration and symptoms of post-workout muscle soreness. The potential benefits of massage include increased blood flow and venous return and reduced soreness $[9,40]$. However, the results of studies concerning the effects of massage as an element of preparation for physical effort are not convergent

Table 2. Results of all tasks of the FMS

\begin{tabular}{rlccccccc}
\hline Groups & Measurement & Deep squat & Hurdle step & In-line lunge & $\begin{array}{c}\text { Shoulder } \\
\text { mobility }\end{array}$ & $\begin{array}{c}\text { Active straight } \\
\text { leg raise }\end{array}$ & $\begin{array}{c}\text { Trunk stability } \\
\text { push-up }\end{array}$ & $\begin{array}{c}\text { Rotary } \\
\text { stability }\end{array}$ \\
\hline \multirow{2}{*}{1} & pre-test & $2.18 \pm 0.61$ & $2.00 \pm 0.54$ & $2.36 \pm 0.73$ & $2.54 \pm 0.88$ & $2.43 \pm 0.84$ & $1.39 \pm 1.13$ & $2.07 \pm 0.38$ \\
& post-test & $2.29 \pm 0.66$ & $2.29^{* *} \pm 0.60$ & $2.43 \pm 0.69$ & $2.61 \pm 0.63$ & $2.54 \pm 0.69$ & $1.86^{*} \pm 0.97$ & $2.11 \pm 0.31$ \\
& pre-test & $1.85 \pm 0.53$ & $2.15 \pm 0.36$ & $2.30 \pm 0.72$ & $2.70 \pm 0.67$ & $2.30 \pm 0.72$ & $1.93 \pm 0.87$ & $2.04 \pm 0.34$ \\
& post-test & $2.19^{* *} \pm 0.56$ & $2.41^{*} \pm 0.51$ & $2.56 \pm 0.51$ & $2.74 \pm 0.53$ & $2.44 \pm 0.70$ & $2.15^{*} \pm 0.91$ & $2.00 \pm 0.48$ \\
\hline
\end{tabular}

Differences between first and second measurements: * $\mathrm{p}<0.05$; $* * \mathrm{p}<0.01 ; * * * \mathrm{p}<0.001$ (Wilcoxon test). 
Table 3. Results of women and men of all tasks of the FMS

\begin{tabular}{|c|c|c|c|c|c|c|c|c|c|}
\hline $\begin{array}{l}\text { Groups } \\
\text { (gender) }\end{array}$ & Measurement & Deep squat & $\begin{array}{l}\text { Hurdle } \\
\text { step }\end{array}$ & $\begin{array}{l}\text { In-line } \\
\text { lunge }\end{array}$ & $\begin{array}{l}\text { Shoulder } \\
\text { mobility }\end{array}$ & $\begin{array}{c}\text { Active straight } \\
\text { leg raise }\end{array}$ & $\begin{array}{c}\text { Trunk stability } \\
\text { push-up }\end{array}$ & $\begin{array}{l}\text { Rotary } \\
\text { stability }\end{array}$ & Sum \\
\hline \multirow{2}{*}{1 (women) } & pre-test & $2.26 \pm 0.62$ & $\begin{array}{c}1.96 \\
\pm 0.46\end{array}$ & $\begin{array}{c}2.39 \\
\pm 0.76\end{array}$ & $\begin{array}{c}2.65 \\
\pm 0.73\end{array}$ & $2.70 \pm 0.72$ & $1.13 \pm 1.02$ & $\begin{array}{c}2.09 \\
\pm 0.36\end{array}$ & $15.17 \pm 2.42$ \\
\hline & post-test & $2.30 \pm 0.61$ & $\begin{array}{l}2.30^{* *} \\
\pm 0.56\end{array}$ & $\begin{array}{c}2.52 \\
\pm 0.62\end{array}$ & $\begin{array}{c}2.74 \\
\pm 0.54\end{array}$ & $2.70 \pm 0.64$ & $1.57 * \pm 1.02$ & $\begin{array}{c}2.09 \\
\pm 0.41\end{array}$ & $16.22 * * \pm 2.28$ \\
\hline \multirow{2}{*}{1 (men) } & pre-test & $1.80 \pm 0.45$ & $\begin{array}{c}2.20 \\
\pm 0.45\end{array}$ & $\begin{array}{c}2.20 \\
\pm 0.45\end{array}$ & $\begin{array}{c}2.00 \\
\pm 1.22\end{array}$ & $1.20 \pm 0.45$ & $2.60 \pm 0.55$ & $\begin{array}{c}2.00 \\
\pm 0.71\end{array}$ & $14.00 \pm 1.87$ \\
\hline & post-test & $2.20 \pm 0.84$ & $\begin{array}{c}2.20 \\
\pm 0.45\end{array}$ & $\begin{array}{c}2.00 \\
\pm 0.71\end{array}$ & $\begin{array}{c}2.00 \\
\pm 0.71\end{array}$ & $1.80 \pm 0.45$ & $2.80 \pm 0.45$ & $\begin{array}{c}2.20 \\
\pm 0.45\end{array}$ & $15.20 \pm 1.30$ \\
\hline \multirow{2}{*}{2 (women) } & pre-test & $1.84 \pm 0.61$ & $\begin{array}{c}2.11 \\
\pm 0.32\end{array}$ & $\begin{array}{c}2.37 \\
\pm 0.83\end{array}$ & $\begin{array}{c}2.84 \\
\pm 0.37\end{array}$ & $2.63 \pm 0.50$ & $1.63 \pm 0.83$ & $\begin{array}{c}2.00 \\
\pm 0.33\end{array}$ & $15.42 \pm 2.61$ \\
\hline & post-test & $2.26 * * \pm 0.56$ & $\begin{array}{l}2.42 * * \\
\pm 0.51\end{array}$ & $\begin{array}{c}2.63 \\
\pm 0.50\end{array}$ & $\begin{array}{c}2.89 \\
\pm 0.32\end{array}$ & $2.74 \pm 0.56$ & $1.95 * \pm 0.97$ & $\begin{array}{c}1.95 \\
\pm 0.52\end{array}$ & $16.84 * * * \pm 2.39$ \\
\hline \multirow{2}{*}{2 (men) } & pre-test & $1.88 \pm 0.35$ & $\begin{array}{c}2.25 \\
\pm 0.46\end{array}$ & $\begin{array}{c}2.13 \\
\pm 0.35\end{array}$ & $\begin{array}{c}2.38 \\
\pm 1.06\end{array}$ & $1.50 \pm 0.53$ & $2.63 \pm 0.52$ & $\begin{array}{c}2.13 \\
\pm 0.35\end{array}$ & $14.88 \pm 1.13$ \\
\hline & post-test & $2.00 \pm 0.53$ & $\begin{array}{c}2.38 \\
\pm 0.51\end{array}$ & $\begin{array}{c}2.38 \\
\pm 0.52\end{array}$ & $\begin{array}{c}2.38 \\
\pm 0.74\end{array}$ & $1.75 \pm 0.46$ & $2.63 \pm 0.52$ & $\begin{array}{c}2.13 \\
\pm 0.35\end{array}$ & $15.63 * \pm 1.06$ \\
\hline
\end{tabular}

Differences between first and second measurements: ${ }^{*} \mathrm{p}<0.05 ; * * \mathrm{p}<0.01 ; * * \mathrm{p}<0.001$ (Wilcoxon test).

$[4,17]$. Sports massage used before warm-up influenced the range of motion in joints as well as the results of motor tests, especially short-term ones (speed, power) $[6,13,37]$. It also had a positive impact on the starting efficiency of players participating in the boxing tournament. However, some researchers come to different conclusions. Arabaci et al. [4] determined the effect of lower limb massage before exercise on selected motor skills through the use of Swedish massage. Their results indicated that massage adversely affected the examined motor features. It was concluded that the massage time was too long and too burdensome for the contestant [4].

However, there are very few studies on manual massage in warm-up. The most frequently indicated positive effects are in preparation for effort [13]. More often, foam rolling was used as a supporting treatment. Here, its effectiveness was also emphasized, particularly in the context of improved muscle flexibility [24, 33, 35].

The Functional Movement Screen test used in this study provides an opportunity to assess the likelihood of injury and existing dysfunctions of the locomotive apparatus. It is a screening test, making it possible to reveal weaknesses in the kinematic chains. It is used to assess movement patterns and functional fitness of athletes $[1,18,23]$. Each of the tests that make up the test provides relevant information. For example, a strong correlation between deep squatting and injury was revealed. Thus, the very attempt at deep squatting may be a prognostic test [19]. The effectiveness of the FMS test is evidenced by the large number of scientific publications in which it is a research tool. This makes it possible to easily and reliably compare the results obtained with those of other authors. Susceptibility tests, using FMS, concerned, among others, athletes, team game players and martial arts adepts $[8,11,16]$.

Looking for alternative forms of preparation for physical activity can not only increase the training effect, but also make the training more attractive. The primary goal of sports or recreational training is to increase the exercise capacity of the system. For this process to be effective, exercises must be performed regularly. It is therefore necessary to prepare the body for every workout.

In view of further research, therefore, it seems justified to investigate a larger group, more diverse in terms of age, health, growth and weight parameters, physical activity or even lifestyle. Additionally, the warm-up can be supplemented with further physiotherapeutic procedures or various forms of exercise and their effect on the body assessed $[22,27]$.

\section{Conclusions}

1. A proper warm-up can have a beneficial effect on minimizing the motion apparatus' functional limitations. It is advisable to perform preparatory exercises before each training session in order to improve the quality of movement and minimize the risk of injury. 
2. There are no significant differences between the group using sports massage and the group using Chinese selfmassage. Both methods can improve movement functionality.

3. The Functional Movement Screen test provides information about functional limitations of the motion apparatus and its dysfunctions that can lead to damage. It can be a diagnostic tool used in the prevention of injuries.

4. Research on the effectiveness of prevention programmes should be continued in different groups, especially among athletes, for whom the risk of injury is highest.

\section{Conflict of interest: Authors state no conflict of interest.}

\section{References}

1. Adamczyk J.G., Boguszewski D., Białoszewski D. (2015) Functional assessment of male track and field runners through functional movement screen test. Med. Sport, 68(4): 563-768.

2. Adamczyk J.G., Boguszewski D., Siewierski M. (2012) Physical effort ability in counter movement jump depending on the kind of warm-up and surface temperature of the quadriceps. Balt. J. Health Phys. Act., 4(3): 164-171.

3. Adamczyk J.G., Gryko K., Boguszewski D. (2020) Does the type of foam roller influence the recovery rate, thermal response and DOMS prevention? PLoS ONE, 15(6): e0235195. DOI: 10.1371/journal.pone.0235195.

4. Arabaci R. (2008) Acute effects of pre-event lower limb massage on explosive and high speed motor capacities and flexibility. J. Sports Sci. Med., 7: 549-555.

5. Arazi H., Asadi A., Hoseini K. (2012) Comparison of two different warm-ups (static stretching and massage): effects on flexibility and explosive power. Acta Kinesiol., 6(1): 55-59.

6. Arroyo-Morales M., Fernández-Lao C., Ariza-García A., Toro-Velasco C., Winters M., Díaz-Rodríguez L., Cantarero-Villanueva I., Huijbregts P., Fernández-De-lasPeñas C. (2011) Psychophysiological effects of preperformance massage before isokinetic exercise. J. Strength Cond. Res., 25(2): 481-488.

7. Bae S.H., Lee Y.S., Kim G.D., Kim K.Y. (2014) A quantitative evaluation of delayed onset muscular soreness according to application of Kinesio Taping. Adv. Sci. Technol. Lett., 47: 387-390.

8. Bagherian S., Ghasempoor K., Rahnama N., Wikstrom E.A. (2019) The effect of core stability training on functional movement patterns in college athletes. J. Sport Rehabil., 28(5): 444-449.

9. Benjamin P.J., Lamp S.P. (2005) Understanding Sports Massage. Human Kinetics. Champaign.
10. Beyleroglu M., Kolayis H., Ramazanoglu F., Hazar M., Cenk A., Bajorek W. (2009) Relation between warm-up with massage before competition and result of the struggle and performance the boxers. Arch. Budo., 5: 25-27.

11. Boguszewski D., Adamczyk J.G., Boguszewska K., Wrzosek D., Mrozek N., Waloch M., Białoszewski D. (2019) Functional assessment of women practising combat sports and team sports using the Functional Movement Screen. Biomed. Hum. Kinet., 11: 90-96.

12. Boguszewski D., Adamczyk J.G., Buda M., Kłoda M., Białoszewski D. (2016) The use of functional tests to assess risk of injuries in judokas. Arch. Budo Sci. Martial Art Extreme Sport, 12: 57-62.

13. Boguszewski D., Kowalska S., Adamczyk J.G., Korabiewska I. (2012) The application of sports massage and self-massage as alternative forms of warm-up support for men regularly doing strength training. Pilot study. Hum. Health, 6(1): 161-166.

14. Boguszewski D., Radomska A., Kerbaum-Visser K., Białoszewski D. (2018) The influence of static and progressive stretching exercises on the functional limitations of the musculoskeletal system. Trends Sport Sci., 1(25): 13-19.

15. Boguszewski D., Szkoda S., Adamczyk J.G., Piesio S., Białoszewski D. (2020) The effects of kinesiotaping applied to delayed-onset muscle soreness of the quadriceps femoris. Phys. Act. Rev., 8: 39-45.

16. Bond C.W., Dorman J.C., Odney T.O., Roggenbuck S.J., Young S.W., Munce T.A. (2019) Evaluation of the functional movement screen and a novel Basketball mobility test as an injury prediction tool for collegiate Basketball players. J. Strength Cond. Res., 33(6): 1589-1600.

17. Brzęk A., Nowotny-Czupryna O. (2004) Wpływ rozgrzewki na wynik próby wysiłkowej pacjentów po zawale mięśnia sercowego. Fizjoterapia, 12(2): 5-12.

18. Chorba R., Chorba D., Bouillon L. (2010) Use of a Functional Movement Screening tool to determine injury risk in female collegiate athletes. N. Am. J. Sports Phys. Ther., 5(2): 47-54.

19. Clifton D., Grooms D., Onate J. (2015) Overhead deep squat performance predicts functional movement screen score. Int. J. Sports Phys. Ther., 10(5): 622-627.

20. Cook G., Burton L., Hoogenboom B.J., Voight M. (2014) Functional Movement Screening: the use of fundamental movements as an assessments of function - part 1. Int. J. Sports Phys. Ther., 3: 396-409.

21. Cook G., Burton L., Hoogenboom B.J., Voight M. (2014) Functional Movement Screening: the use of fundamental movements as an assessments of function - part 2. Int. J. Sports Phys. Ther., 4: 549-563.

22. Fuller J.T., Lynagh M., Tarca B., Zacharia A., Townsley A., Gleeson C., Chalmers S. (2020) Functional Movement Screen Pain Location and Impact on Scoring Have 
Limited Value for Injury Risk Estimation in Junior Australian Football Players. J. Orthop. Sport Phys., 50(2): $75-82$.

23. Garrison G., Westrick R., Johnson M. (2015) Association between the Functional Movement Screen and injury development in college athletes. Int. J. Sports Phys. Ther., 10(1): 21-28.

24. Harley K., Hatfield D., Blanpied P. (2014) The effects myofascial release with foam rolling on performance. $J$. Strength Cond. Res., 28(1): 61-68.

25. Hin K. (1989) Chinese massage and acupressure. Bern.

26. Kalina R.M., Jagiełło W., Barczyński B.J. (2013) The method to evaluate the body balance disturbation tolerance skills - validation procedure of the Rotational Test. Arch. Budo., 9(1): 59-80.

27. Lockie R., Schultz A., Callaghan S. (2015) A preliminary investigation into the relationship between functional movement screen scores and athletic physical performance in female team sport athlete. Biol. Sport, 32: 41-51.

28. Maiiou P., Rokka S., Beneka A., Mavridis G., Godolias G. (2007) Reducing risk of injury due to warm up and cool down in dance aerobics instructors. J. Back Musculoskelet., 20: 29-35.

29. Mandengue S.H., Miladi I., Bishop D., Temfemoa A., Cisse F., Ahmaidi S. (2009) Methodological approach for determining optimal active warm-up intensity: predictive equations. Sci. Sports. 24(1): 9-14.

30. Mosler D. (2015) Validity and reliability of non-apparatus and quasi apparatus flexibility tests - verification during health-related training based on judo. Arch. Budo Sci. Martial Art Extreme Sport, 11: 123-133.

31. Obałkowska A. (2003) Naciągnięcia mięśni - mechanizmy urazu. zapobieganie. Fizjoterapia, 11(4): 37-50.

32. Page P. (2012) Current concepts in muscle stretching for exercise and rehabilitation. Int. J. Sports Phys. Ther., 7(1): 109-119.
33. Peacock C.A., Krein D.D., Silver T.A., Sanders G.J., Von Carlowitz K.P.A. (2014) An acute bout of self-myofascial release in the form of foam rolling improves performance testing. Int. J. Exerc. Sci., 7(3): 202-211.

34. Shier I. (2008). Warm-up and stretching in the prevention of muscular injury. Sport Med., 38(10): 879-880.

35. Su H., Chang N.J., Wu W.L., Guo L.Y., Chu I.H. (2017) Acute effects of foam rolling, static stretching, and dynamic stretching during warm-ups on muscular flexibility and strength in young adults. J. Sport Rehabil., 26(6): 469-477.

36. Subasi S.S., Gelecek N., Aksakoglu G. (2008) Effects of different warm-up periods on knee proprioception and balance in healthy young individuals. J. Sport Rehab., 17: 186-205.

37. Woods K., Bishop P., Jones E. (2007) Warm-up and stretching in the prevention of muscular injury. Sport. Med., 37(12): 1089-1099.

38. Yamaguchi T., Takizawa K., Shibata K., Tomabechi N., Samukawa M., Yamanaka M. (2019) Effect of General Warm-Up Plus Dynamic Stretching on Endurance Running Performance in Well-Trained Male Runners. Res. $Q$. Exercise Sport, 90(4): 527-533.

39. Zhang S., Fu W., Pan J., Wang L., Xia R., Liu Y. (2016) Acute effects of Kinesio taping on muscle strength and fatigue in the forearm of tennis players. J. Sci. Med. Sport, 19(6): 459-464.

40. Zhong H., Wang C., Wan Z., Lei J. (2019) The possible mechanisms of massage therapy. Biomed. Res., 30: 1-6.

\section{Received 20.10.2020 \\ Accepted 30.11.2020}

(c) University of Physical Education, Warsaw, Poland 